\title{
Archaeological Test Excavations at 41KF118 Kaufman County, Texas
}

John W. Clark Jr.

Follow this and additional works at: https://scholarworks.sfasu.edu/ita

Part of the American Material Culture Commons, Archaeological Anthropology Commons, Environmental Studies Commons, Other American Studies Commons, Other Arts and Humanities Commons, Other History of Art, Architecture, and Archaeology Commons, and the United States History Commons

Tell us how this article helped you.

This Article is brought to you for free and open access by the Center for Regional Heritage Research at SFA ScholarWorks. It has been accepted for inclusion in Index of Texas Archaeology: Open Access Gray Literature from the Lone Star State by an authorized editor of SFA ScholarWorks. For more information, please contact cdsscholarworks@sfasu.edu. 


\section{Archaeological Test Excavations at 41KF118 Kaufman County, Texas}

\section{Licensing Statement}

This is a work produced for the Texas Department of Transportation (TxDOT) by the report producer. TxDOT and the report producer jointly own all rights, title, and interest in and to all intellectual property developed under TXDOT's contract with the report producer. The report may be cited and brief passages from this publication may be reproduced without permission provided that credit is given to both TxDOT and the report producer. Permission to reprint an entire chapter, section, figures or tables must be obtained in advance from either the Supervisor of the Archeological Studies Branch, Environmental Affairs Division, Texas Department of Transportation, 125 East 11th Street, Austin, Texas, 78701 or from the report producer. 


\section{ARCHAEOLOGICAL TEST EXCAVATIONS AT 41KF118 \\ KAUFMAN COUNTY, TEXAS}

\section{B y}

John W. Clark, Jr.

Texas State Department of Highways and

Public Transportation

A ustin, Texas

June 1990 
TABLE OF CONTENTS

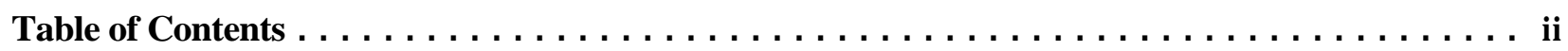

List of Figures and Table $\ldots \ldots \ldots \ldots \ldots \ldots \ldots \ldots \ldots \ldots \ldots \ldots \ldots \ldots$ iii

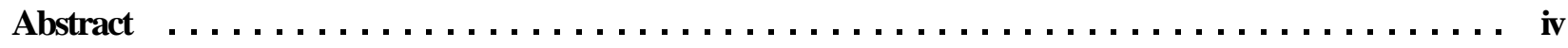

Introduction $\ldots \ldots \ldots \ldots \ldots \ldots \ldots \ldots \ldots \ldots \ldots \ldots \ldots \ldots \ldots \ldots \ldots$

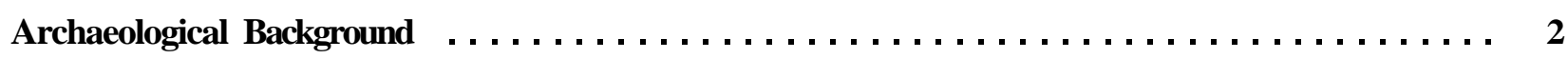

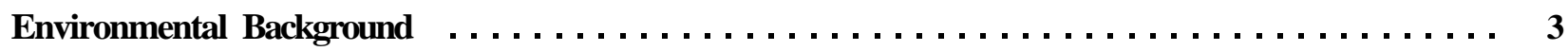

Site Description $\ldots \ldots \ldots \ldots \ldots \ldots \ldots \ldots \ldots \ldots \ldots \ldots \ldots \ldots \ldots \ldots \ldots \ldots \ldots$

Objectives and Methods of Testing $\ldots \ldots \ldots \ldots \ldots \ldots \ldots \ldots \ldots \ldots \ldots \ldots \ldots \ldots \ldots \ldots$

Resultsof Testing $\ldots \ldots \ldots \ldots \ldots \ldots \ldots \ldots \ldots \ldots \ldots \ldots \ldots \ldots \ldots$

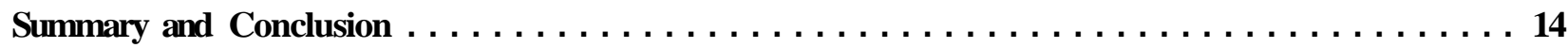

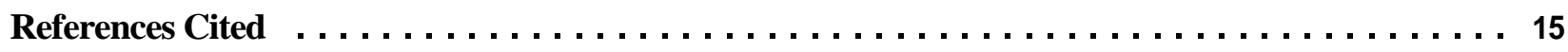




\section{LIST OF FIGURES AND TABLE}

FIGURE 1. Location of Site 41KF118 in Kaufman County $\ldots \ldots \ldots \ldots \ldots \ldots \ldots \ldots$

FIGURE 2. Site plan and test units $\ldots \ldots \ldots \ldots \ldots \ldots \ldots \ldots \ldots \ldots \ldots$

FIGURE3. Site $41 K$ F 118 profiles $\ldots \ldots \ldots \ldots \ldots \ldots \ldots \ldots \ldots \ldots \ldots \ldots$

FIGURE 4. Artifacts recovered from Site $41 \mathrm{KF} 118 \ldots \ldots \ldots \ldots \ldots \ldots \ldots \ldots$

TABLE 1. Items recovered $\ldots \ldots \ldots \ldots \ldots \ldots \ldots \ldots \ldots \ldots \ldots \ldots \ldots \ldots \ldots \ldots$ 


\begin{abstract}
Site 41KF118 was discovered during construction of improvements to SH 34 in Kaufman County and was tcstcd in April 1990, to determine its eligibility for inclusion in the National Register of Historic Places. Materials recovered as a result of test excavations suggest a Late Archaic occupation for that portion of the site within the right-of-way. Most of the site lies southeast of the highway right-of-way. Tests also showed the cultural deposits to be sparse and badly disturbed by previous land clearing operations and cultivation. No additional work is recommended at this site.
\end{abstract}




\section{INTRODUCTION}

As a result of local interest in the cultural resources along the right-of-way of State Highway 34, site $41 \mathrm{KF} 118$ was discovered and recorded after construction had begun on a project to convert the present two-lane highway to a four-lane facility. Testing was recommended on site 41K F 118 and was performed during the week of April 2, 1990 with personnel provided by the State Department of Highways and Public Transportation (SDHPT), Dallas District Environmental group. The crew consisted of Mary May, Jan Wagner and Mike Renfrow. Work was performed in order to evaluate that part of the site within the right-of-way to determine its eligibility for inclusion into the National Register of Historic Places pursuant to Executive Order 11593.

State Highway 34 runs northeast from Terrell crossing King's Creek and travcrsing the site area. The site was found on the north terrace of a branch of King's Creek on the east side of the road. Previous to purchase by the SDHPT, the site area had been cultivated in cotton. Subsequent to right-of-way acquisition in the early 1970s the site area was cleared and trees on the site were burned. When the site was found, construction in the area of the site ceased. 


\section{ARCHAE OLOGICAL BACKGROUND}

Archaeological investigations in Kaufman County and its immediate environs have largely consisted of a number of negative surveys. Many of these are discussed in a publication of the Texas Historical Commission (Review and Compliance Staff 1985). Several involved Soil Conservation Service surveys of Cedar Creek and StaTe Department of Highways and Public Transportation surveys of farm-to-market roads of which no sites were found. Other minor surveys included Texas Department of Water Resources surveys and the survey of one transmission line. Of some 26 surveys, no sites were found on 20 one of these surveys. On the five surveys on which sites were found there were a total of eight sites recorded.

Two larger reports have been published., One was a survey of Cedar Creek by W.A. Davis (1961) of the Texas Archeological Salvage Project in which several sites were located. Perhaps the best report was by Dee Ann Story (1965). She excavated three sites dividing the sequences into several periods. Her period 3 (Late Archaic) appeared to be the equivalent of the occupation of this site. Although Story stated that Bristol bifaces and Gary dart- points, Williams Plain pottery, pitted stones, scrapers, celts and bifaces characterized the later portions of this period (Story 1965: 250), all categories mentioned were not represented. It is possible that this site is an expression of the early portion of Story's Period 3.

The Early Archaic and later Alto and Wylie foci and other post Archaic phenomena do not seem to pertain to the cultural developments exhibited at the right-of-way portion of this site. No evidence of Paleo-Indian, early Archaic or Post Archaic development appears in the artifact inventory recovered from this site although they have been found at other sites in the county. 


\section{ENVIRONMENTAL BACKGROUND}

K aufman County lies well within the Blackland Prairie region of Texas (Gould 1969:11). Generally soils are dark calcareous clays covered with little bluestem grass and other grasses to a lesser extent. Mesquite appears in some areas and post and blackjack oaks are found in the lighter soils.

Soil on the site appears to be a part of the Lufkin-Radar complex composed of Lufkin fine sandy loam on low mounds $30-125 \mathrm{ft}(10-40 \mathrm{~m})$ in diameter (Pringle 1977:19). The underlying geological deposits appear to be the Kincaid formation of the midway group of the Eocene (Sellards, Adkins and Plummer 1932:531-540). 


\section{SITE DESCRIPTION}

The site is situated on the terrace above a branch of King's Creek about 1460 meters due south of the north Kaufman county boundary and about 1980 meters southwest of the point where SH 34 crosses the county line (Fig. 1). It is on the right branch of the tributary. The terrace appears as a long ridge oriented approximately north-south, lowering in elevation as it approaches the north. The ridge is cut bySH 34. The pasture adjacent to the road on either side has been cleared of trees and planted in coastal Bermuda grass. Trees are now seen principally in the creek bottoms and where houses have been constructed. According to the owners, the land had formerly been cultivated in cotton and the trees had been removed and burned in the site area. They also stated that for more than 400 meters to the south southeast of SH 34, they had found numerous dart points. The site could beestimated to be 450 meters long, northwest to southeast, and at least 50 meters wide, northeast to southwest.

On the backslope cut of SH 34, at the western extremity of the site, sterile clay was evident from virtually the top of the cut to the base, approximately five meters. At the top of the ridge there was a thin cap of brown sandy loam containing cultural material eroding out of the top of the backslope cut. This material consisted of small burned quartzite cobbles, quartzite and chert flakes. All of these occurred at the crest of the ridge and, according to the landowners, were to be found in concentrations on other parts of the site outsidc the right-of-way. 
This Page Redacted Per THC Policy 


\section{OBJECTIVES AND METHODS OF TESTING}

The principal objective of testing this site was to determine its potential for eligibility for listing on the National Register of Historic Places. In order to do this it was necessary to determine the extent of the site within the right-of-way, the depth and nature of disturbances, to discover the depth of the cultural deposits, the age of the site, and the presence or absence of undisturbed buried features.

In order to determine the nature of the site within the right-of-way it was first necessary to determine the most obvious areas and extent of disturbance. These were immediately along the right-of-way fence and along the upper edge of the backslope. A series of one-by-one-meter test units were then placed 1.5 meters away from the right-of-way fence in order to avoid the fence line disturbance and parallel to the fence to determine the site extent within the right-of-way (Fig. 2). All units were dug in $10 \mathrm{~cm}$ levels measured from the surface and screened through $\mathbf{1 / 4} \mathrm{in}$. hardware cloth. All burned rocks, flakes, and artifacts (and other materials indicating disturbance) were collected and placed in bags labeled with the site number, unit number, depth and date. All units were dug slightly into recognizably sterile clay of the Kincaid formation of Eocene age.

Units were placed five meters apart parallel to the right-of-way fence to locate site limits and artifact concentrations. Each unit was examined for the presence of undisturbed features and profiled to record major disturbances. Floor plans were drawn only when there was visible variation in the deposit at the base of a level. Records included a daily log, field notes for each unit, a bag $\log$, list of photographs, and catalog of recovered artifacts. The site owners (owners for more than 40 years) were consulted regarding previous disturbance, cultivation practices and the locations at which they noted the presence of prehistoric artifacts. 


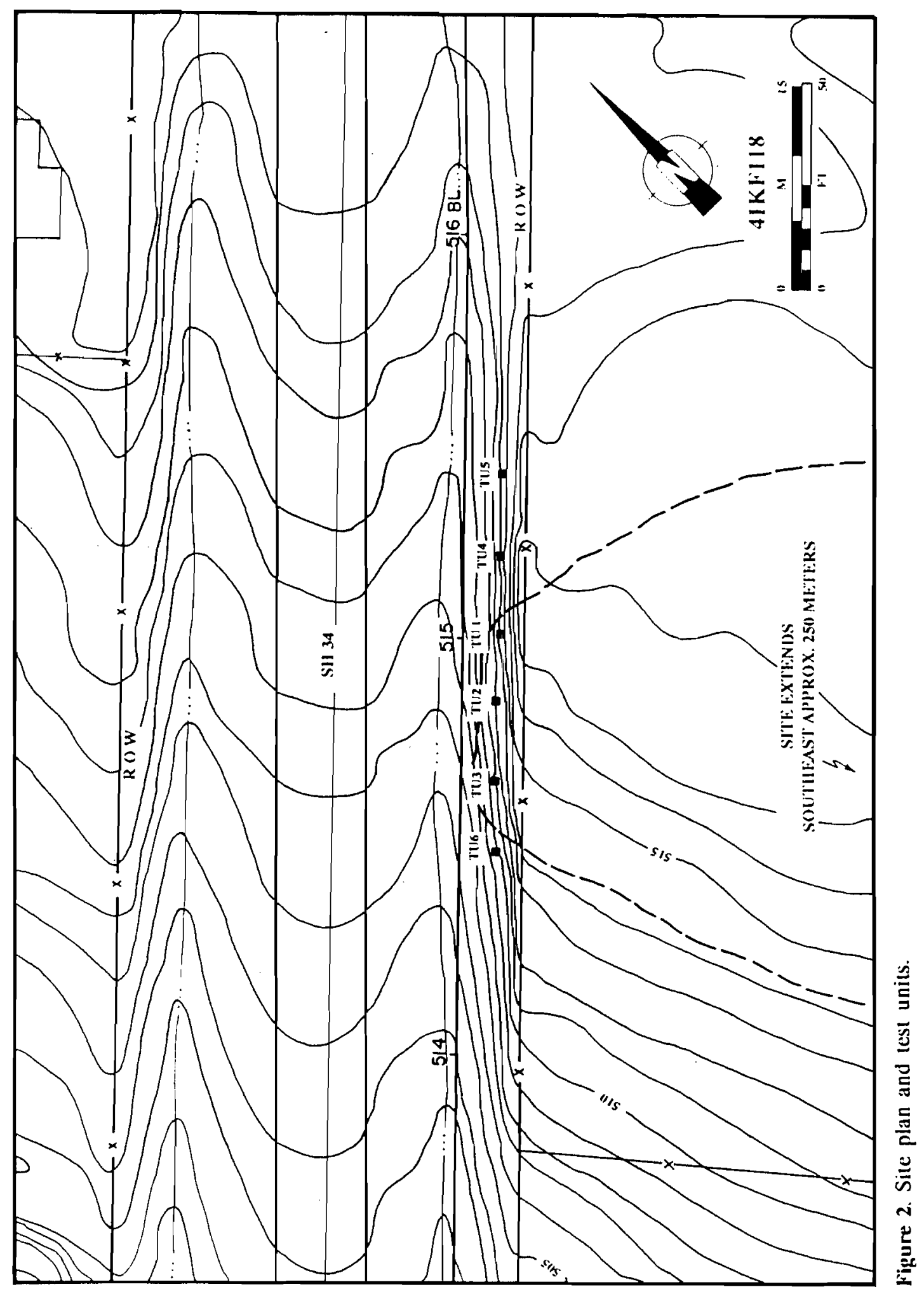




\section{RESULTS OF TESTING}

A total of six 1-by-1 meter units were excavated. Two were excavated to a depth of $\mathbf{3 0} \mathrm{cm}$ below the surface, three to a depth of $\mathbf{2 0} \mathrm{cm}$ and one to a depth of $10 \mathrm{~cm}$. All were excavated into the basal red clay. Test units one through three were excavated on the crest of the knoll, test units four and five were located to the northeast or on the eastern slope of the ridge and test unit six was on the western slope of the ridge southwest of the units located on the crest. Units 1, 2, and 3 contained a moderate amount of cultural material while the remaining three were virtually devoid of cultural debris.

\section{STRATIGRAPHY}

Test Unit 1 (Fig. 3)

The upper $\mathbf{1 0}$ to $15 \mathrm{~cm}$ of deposit of this unit consisted of mixed sterile red clay and a medium brown sandy loam and fragments of burned and partially burned wood. This zone appears to represent the disturbance associated with theoriginal clearing of the right-of-way of trees. The second zone, from about $\mathbf{1 2 - 1 5} \mathrm{cm}$ below the surface to $\mathbf{2 5 - 2 8} \mathrm{cm}$ below the surface, consisted of a medium brown sandy loam with some burned wood and evidence of numerous rodent runs. Excepting the rodent runs, this zone appeared fairly homogeneous perhaps reflecting the previous cultivation of the site. Sterile sand and clay occupied the remainder of the deposit to $\mathbf{3 0} \mathrm{cm}$.

\section{Test Unit 2 (Fig. 3)}

The upper 25 to $28 \mathrm{~cm}$ consisted of medium brown sandy loam with some dense red clay in the upper $5 \mathrm{~cm}$ of this deposit. The lower $\mathbf{3 - 5} \mathrm{cm}$ consisted of sterile gray sand and red clay. A distinct upper disturbed zone was not obvious but the lumps of red clay in the upper $\mathbf{5} \mathrm{cm}$ indicated it was present.

\section{Test Unit 3}

The upper $10 \mathrm{~cm}$ consisted of medium brown sandy loam mixed with lumps of red clay and burned wood fragments. This overlaid a thin zone of light brown sand in the lower $\mathbf{1 0} \mathrm{cm}$. The base of the unit was excavated into the red basal clay. 


\section{KF 118 \\ PROFILES}

Test Unit I South Wall

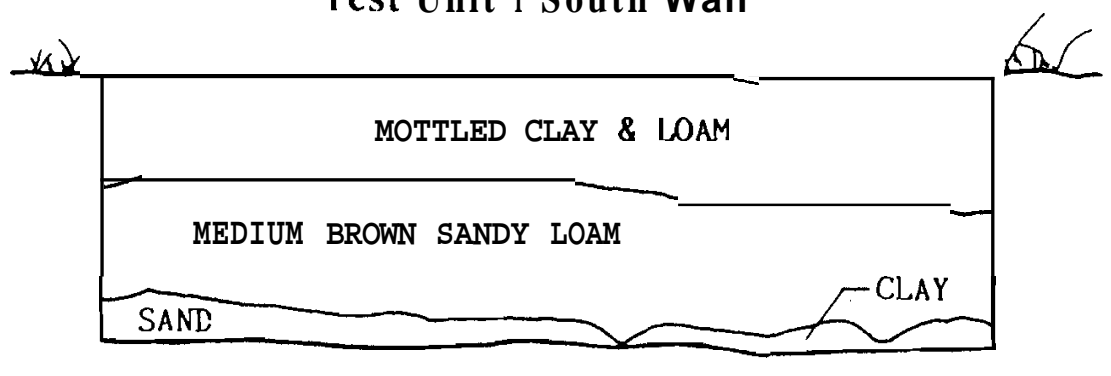

Test Unit 2 North Wall

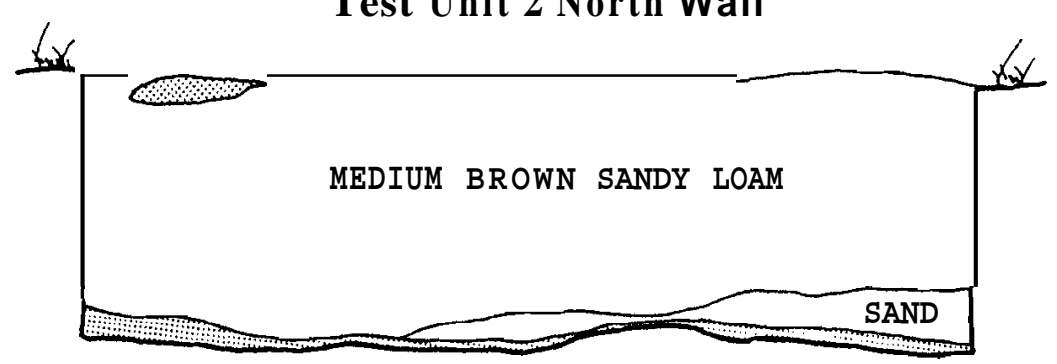

Test Unit 5 North Wall
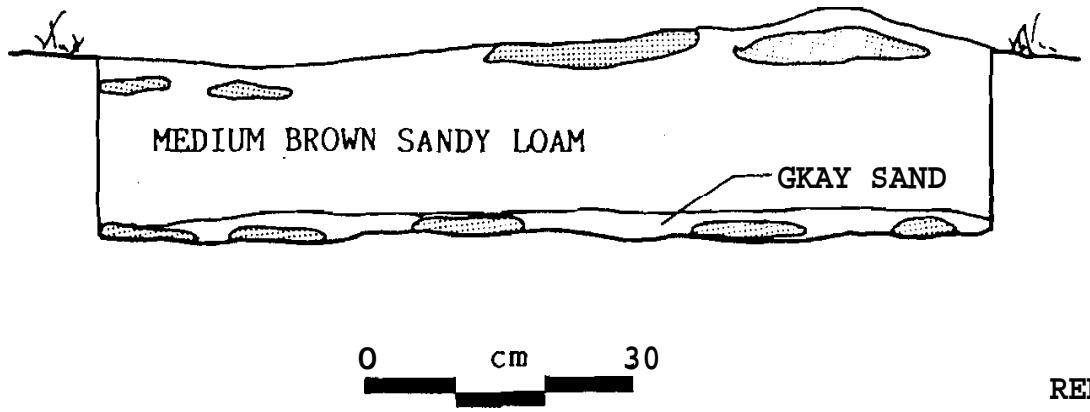

RED CLAY

Figure 3. Site $41 \mathrm{KF} 118$ profiles. 


\section{Test Unit 4}

A thin zone, about $2 \mathrm{~cm}$ thick, of light brown sand overlaid the top of this unit. This zone is interpreted as slope wash from surrounding areas as this unit was in a shallow swale. Below the slope wash was a zone almost $20 \mathrm{~cm}$ thick of dark brown sandy clay. The upper portion of this zone contained burned wood and four flakes, probably from the upper slope wash. No other items were recovered. The unit was excavated 2 to $3 \mathrm{~cm}$ into the basal red clay.

\section{Test Unit 5 (Fig. 3)}

This unit was the most northeasterly unit of the series and was excavated to a depth of $20 \mathrm{~cm}$. The majority of the deposit was a medium brown sandy loam with lumps of red clay in the upper $5 \mathrm{~cm}$. Gray sand and red clay occupied the lower $2-3 \mathrm{~cm}$ of the deposit in the unit. No artifacts were recovered from the unit.

\section{T est Unit 6}

Excavated as the southwesternmost unit, a deposit of about $10 \mathrm{~cm}$ of medium brown sandy loam overlying red clay was found. Recovery of artifacts was very small. It is believed that this unit marks the southwestern limit of the site.

\section{ARTIFACT RECOVERY}

Relatively few artifacts were encountered in the excavations. All recovered materials are presented in Table 1.

Glass (1 specimen)

A small fragment of arsenic bleached cylindrical bottle.

Dart Point Tip (4 specimens, Fig. 4A-C)

All are relatively broad and thick bifacially chipped quartzite of fairly triangular bifaces having slightly convex edges. 


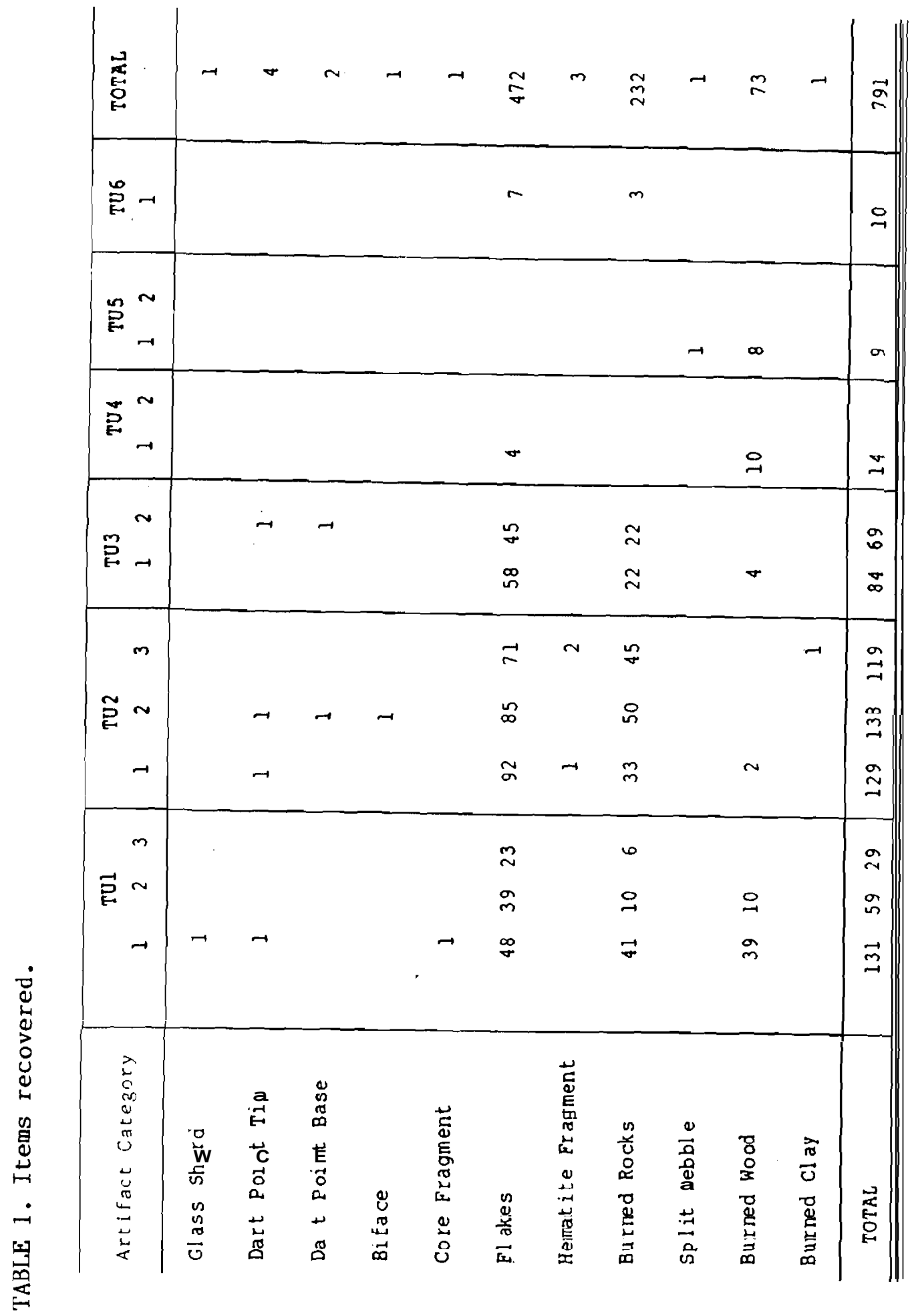




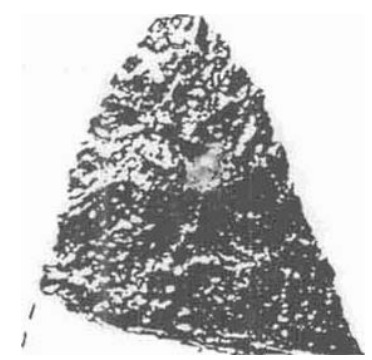

A

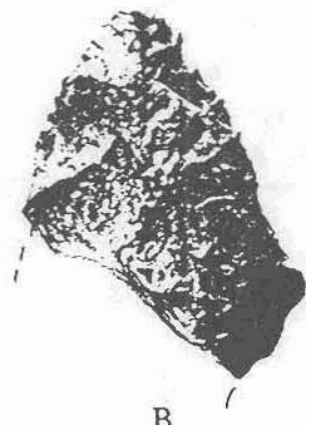

B

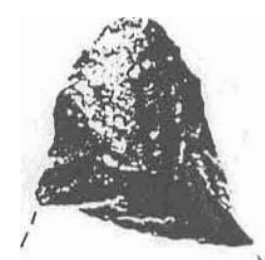

C

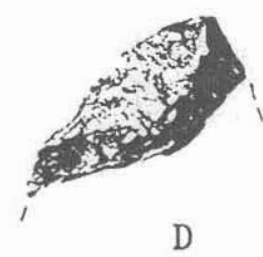

D

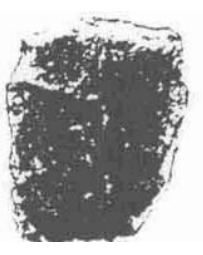

E

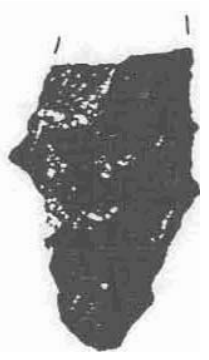

F

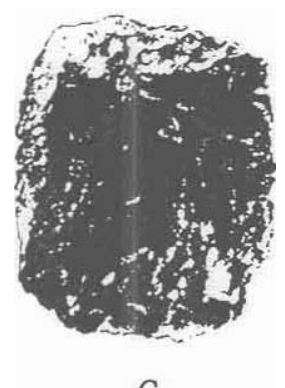

G

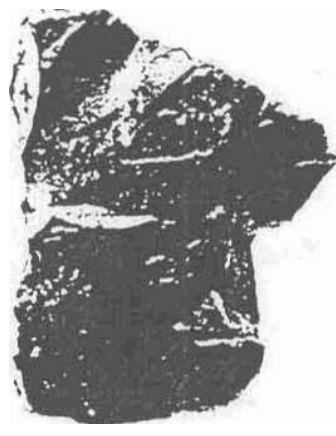

$\mathrm{H}$

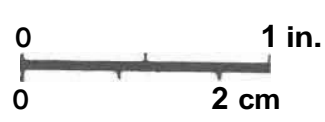

Figure 4. Artifacts recovered from Site 41KF118. 
Dart Point Base (2 specimens, Fig. 4D,E)

One specimen is made of chert and is essentially rectangular in form with slightly convex edges. It is broken at the top of the stem and quite worn along this break. The second specimen is a relatively small fragment of a Gary point made of small-grained quartzite.

Biface (1 specimen, Fig. 4F)

Made of petrified wood this rectangular item with convex edges measures $34 \times 2 \times 6 \mathrm{~mm}$.

Core Fragment (1 specimen, Fig. 4G)

The specimen is a roughly cubical block of fine-grained quartzite having cortex on one face and small flakes removed. At least portions of the surfaces appear to have been heatdamaged.

Flakes (472 specimens)

A II are small specimens made of chert and quartzite. No further analysis is attempted.

Hematite fragments (3 specimens)

All are small (less than $1 \propto$. in volume) and of the variety known as red ocher.

Burned Rocks (232 specimens)

The vast majority of burned rocks were small quartzite rocks, generally less than $20 \propto$. in volume. A very small number of burned limestone rocks were found. These were generally smaller than the last joint of the thumb. No real concentrations were found that could be interpreted as a feature.

Split Pebble (1 specimen)

This is most likely a small naturally occurring piece of gravel.

Burned Wood (73 specimens)

Fragments of trees burned on the site during the clearing of the right-of-way.

Burned Clay (1 specimen)

A small lump less than $1 \mathrm{cc}$. in volume probably the result of treeburning.

It is evident that Test Units $1-3$ were well within the site area and that 4 - 6 were outside the main area of the occupation. No evidence of occupation was found on the opposite side of the road. This suggests that the portion of $41 \mathrm{KF} 118$ within the right-of-way is a peripheral edge. Following the comments of the land owners, it would appear that the major part of the site lies to the south southeast of the right-of-way. Also evident is that the maximum depth of cultural deposit is $30 \mathrm{~cm}$ in the right-of-way and that this deposit is badly disturbed by clearing, cultivation and ongoing rodent activity. No intact features were found. 


\section{SUMMARY A ND C O NCLUSIONS}

The site w as tested to determine potential eligibility for nomination to the National Register of Historic Places (NRHP) for that portion of the site within the right-of-way. It was found that the site extended less than 20 meters along the right-of-way and was disturbed by cultivation, clearing and rodents to the depth of the sterile basal clay. No intact features were found. The age of the site is thought to correspond to Story's (1965) period 3 or LateArchaic on the basis of the small $\mathrm{G}$ ary point found in the excavations. No arrowpoint fragments or ceramics were found nor were any clearly Early Archaic or Paleo-lndian points or point fragments noted.

Remembering the objectives previously stated, it is clear that that portion-of the site within the right-of-way does not meet the criteria for inclusion in the NRHP. It was found to have highly disturbed deposits, no intact features and limited extent. It is also evident that the great majority of the site is south of the right-of-way and appears to be less disturbed although it has been cultivated to the extent that undisturbed deposits may or may not be present. 


\section{REFERENCES C ITE D}

Crook, Wilson W., Jr. and R.K. Harris

1952 Trinity A spect of the Archaic Horizon: The Carrollton and Elam Foci. Bulletin of the Texas Archaeological and Paleontological Society 23: 7-38.

1954 Traits of the Trinity Aspect Archaic: Carrollton and Elam Foci. The Record 12 (1): 2-16. Dallas Archeological Society, Dallas.

Davis, W.A.

1961 Archeological Survey and Appraisal of Cedar Creek Reservoir, Henderson and K aufman Counties, Texas. Texas A rcheological Salvage Project. The University of Texas at Austin.

Gould, F.W.

1969 Texas Plants: A Checklist and Ecological Summary. Texas Agricultural Experiment Station M.P. 585. Texas A \& M University, College Station.

Harris, R.K.

1936 Indian Campsites of the Upper Trinity River Drainage. Bulletin of the Texas Archeological and Paleontological Society 8: 113-133.

1948 Preliminary Report on an Alto Focus Site in Kaufman County. The Record 7 (4): 13-15. Dallas County Archeological Society, Dallas.

Hatzenbuchler, Robert C.

1948 Culture Traits Ragland Site. The Record 6 (8): 32-33. Dallas County Archeological Society, Dallas.

Pringle, Fred B.

1977 Soil Survey of Kaufman and Rockwall Counties, Texas. United States Department of Agriculture, Soil Conservation Service. Washington, D.C.

Review and Compliance Staff

1985 A Bibliography of Reports: Federal Project Review. State Historic Preservation Office, Texas Historical Commission. Austin.

Ross, Richard E.

1966 The Upper Rockwall and Glen Hill sites, Forney Reservoir, Texas. Papers of the Texas Archeological Salvage Project, No. 9. The University of Texas, Austin. 
Sellards, E.H., W.S. Adkins and F.B. Plummer

1932 The Geology of Texas, Vol. I, Stratigraphy. The University of Texas Bulletin No. 3232. The University of Texas. Austin.

Shafer, Harry J.

1964 An Appraisal of the Archeological Resources of Bardwell Reservoir, Ellis County Texas. Texas Archeological Salvage Project. The University of Texas, Austin.

Sorrow, Willlam M.

1966 The Pecan Springs Site, Bardwell Reservoir. Papers of the Texas Archeological Salvage Project, No. 10. The University of Texas, Austin.

Stephenson, Robert L.

1952 The Hogge Bridge Site and the Wylie Focus. American Antiquity 17 (4): 299-312.

Story, D ee Ann

1965 The Archeology of Cedar Creek Reservoir, Henderson and Kaufman Counties, Texas. Bulletin of the Texas Archeological Society 36: 163-258. 